\title{
Kumanoa mablacensis (Batrachospermales, Rhodophyta) in a Mediterranean coastal wetland, a new species for the European continental algal flora
}

\author{
María-Eugenia García-Fernández ${ }^{1 *}$, Morgan L. Vis ${ }^{2} \&$ Marina Aboal $^{1}$ \\ ${ }^{1}$ Laboratorio de Algología, Departamento de Biología Vegetal, Facultad de Biología. Campus de Espinardo. \\ Universidad de Murcia, E-30100 Murcia,España.marujegf@gmail.com, maboal@um.es \\ ${ }^{2}$ Department of Environmental and Plant Biology, Porter Hall, Ohio University, Athens OH 45701, USA. vis-chia@ohio.edu
}

\begin{abstract}
García-Fernández, M.-E., Vis, M.L. \& Aboal, M. 2015. Kumanoa mahlacensis (Batrachospermales, Rhodophyta) in a Mediterranean coastal wetland, a new species for the European continental algal flora. Anales Jard. Bot. Madrid 72(1): e018

Morphological characters and molecular sequence data of the plastidencoded RUBISCO large subunit gen ( $r b \mathrm{CL}$ ) confirmed the first record of Kumanoa mahlacensis (S. Kumano \& W.A. Bowden-Kerby) Entwisle, M.L. Vis, W.B. Chiasson, Necchi \& A.R. Sherwood in Europe from a Spanish Mediterranean coastal wetland. The genus Kumanoa has a worldwide distribution and inhabits in both lotic and lentic habitats, but information about the ecological requirements of species is scarce. In this study, the morphology and ecology of Spanish material is described in order to gain a broader insight of the distribution of species from Mediterranean areas.
\end{abstract}

Keywords: Batrachospermum, distribution, irrigation ditch, Kumanoa, molecular analysis, nutrients, rbcL, Rhodophyta, Spanish Mediterranean coastal wetland.

\section{INTRODUCTION}

Taxonomy of the genus Batrachospermum (Batrachospermales) has been based primarily on the morphology of reproductive characters (Sirodot, 1884; Bourrelly, 1970; Entwisle \& al., 2009; Eloranta \& al., 2011). In an effort to delimit natural groups, in recent years, some sections of Batrachospermum have been raised to genus level and our knowledge enlarged by several new species described (Necchi, 1987; Sheath \& Whittick, 1995; Kumano, 2002; Entwisle \& al., 2009; Necchi \& al., 2010).

The genus Kumanoa has been proposed for species previously assigned to the Contorta and Hybrida sections of Batrachospermum (Entwisle \& al., 2009). Kumanoa differs from Batrachospermum primarily by the combination of hemispherical carposporophytes central in the whorl and the carpogonial branches clearly curved, twisted or spirally coiled (Entwisle \& al., 2009; Necchi \& al., 2010). Phylogenetic analyses based on the large subunit of ribulose 1,5-biphosphate carboxylase/oxygenase $(r b c \mathrm{~L})$ and the small subunit ribosomal RNA (SSU rDNA) genes demonstrated the newly proposed genus to be monophyletic (Vis \& al., 1998; Vis \& Entwisle, 2000; Vis \& al., 2005; Necchi \& al., 2010).

At present, 35 species are recognized in the genus, most of them with a worldwide distribution (Entwisle \& al., 2009; Necchi \& al., 2010; Necchi \& Vis, 2012). Six species have been

\section{Resumen}

García-Fernández, M.-E., Vis, M.L. \& Aboal, M. 2015. Kumanoa mahlacensis (Batrachospermales, Rhodophyta) en un marjal costero mediterráneo, una nueva especie para la flora ficológica contiental europea. Anales Jard. Bot. Madrid 72(1): e018

El estudio de los caracteres morfológicos y las secuencias del gen plastidial ( $r b c \mathrm{~L}$ ) que codifica la subunidad mayor de la enzima RUBISCO han confirmado la presencia de Kumanoa mahlacensis (S. Kumano \& W.A. Bowden-Kerby) Entwisle, M.L. Vis, W.B. Chiasson, Necchi \& A.R. Sherwood en Europa, en un marjal costero mediterráneo del levante español. El género Kumanoa presenta una distribución mundial y habita tanto en ambientes lóticos como leníticos; sin embargo existe poca información sobre los requerimientos ecológicos de esta especie. En este trabajo se describe la morfología y ecología del material recolectado en España con el objetivo de obtener una visión más amplia de su distribución y de su presencia en áreas mediterráneas.

Palabras clave: Batrachospermum, distribución, azarbe, Kumanoa, análisis molecular, nutrientes, rbcL, Rhodophyta, marjal mediterráneo español.

recorded in Europe: Kumanoa abilii (Reis) Necchi \& M.L. Vis, K. henriquesiana (Reis) Necchi \& M.L. Vis, K. lusitanica (Reis) Necchi \& M.L Vis, K. pseudocarpa (Reis) Necchi \& M.L. Vis from Portugal (Reis, 1965, 1972, 1973; Necchi \& Vis, 2012), K. globospora (Israelson) Entwisle, M.L. Vis, W.B. Chiasson, Necchi \& A.R. Sherwood in Sweden (Israelson, 1942), and K. virgatodecaisneana (Sirodot) Entwisle, M.L. Vis, W.B. Chiasson, Necchi \& A.R. Sherwood in France (Sirodot, 1884), Sweden (Israelson, 1942) and Finland (Eloranta \& Kwandrans, 2007). However, only genetic data from three of the taxa ( $K$. abilii, $K$. globospora and K. virgatodecaisneana) are known and even for these species, those data come from specimens collected in continents other than Europe (Entwisle \& al., 2009; Necchi \& al., 2010; Vis \& al., 2012).

Kumanoa mablacensis was originally included in Batrachospermum section Contorta as Batrachospermum mablacense (Kumano \& Bowden-Kerby, 1986). It is characterized by primary fascicles up to 9 cell-storeys, numerous secondary fascicles, asymmetric carpogonium, carpogonial branches curved, twisted or tightly coiled, with 5-15 barrel-shaped cells clearly different from the fascicles cells and 1-2 hemispheric carposporophytes up to $170 \mu \mathrm{m}$ in diameter (Kumano, 2002). It is distinguished from closely related species by having dense carposporophytes lower than the whorl, abundant secondary fascicles and smaller carposporangia (Necchi \& Vis, 2012). This taxon was first described from a river in Guam, a Pacific island 
with tropical climate, on volcanic terrains, with an average precipitation of $2.000 \mathrm{~mm}$ per year (Kumano \& Bowden-Kerby, 1986). Later, it was reported from shallow streams in a mixed deciduous forest of the tropical area of Tambol Huay Kha Yeng, Amphur Thong Pha Phum, Thailand (Traichaiyaporn \& al., 2004), and in two dry areas of the southwestern USA, Upper Tonsil Lake Carlsbad Springs Park, New Mexico and West Big Prong Creek, Texas (Vis \& al., 2012).

In this study, Kumanoa mablacensis is reported for the first time in Europe, the morphological and ecological characteristics of the Spanish material are compared with the literature and sequence data are provided to confirm the identity.

\section{MATERIALS AND METHODS}

\section{Study area}

The specimens were collected in an irrigation ditch from Pego-Oliva Natural Park located between the towns of Pego and Oliva (Valencia-Alicante, Spain) (Figs. 1, 2a). PegoOliva Natural Park is one of the most important wetlands on the Spanish Mediterranean coast with about $14 \mathrm{~km}^{2}$ fed by groundwater. The average annual rainfall and temperature is $905 \mathrm{~mm}$ and $18^{\circ} \mathrm{C}$, respectively (Viñals \& al., 1990). These climatological characteristics explain the subtropical character of the vascular flora (Boira, 1988; Carretero, 1990). The high salinity gradient from freshwater to brackish and the various levels of nutrient concentrations also contribute to the floristic richness and algal biodiversity of the area.

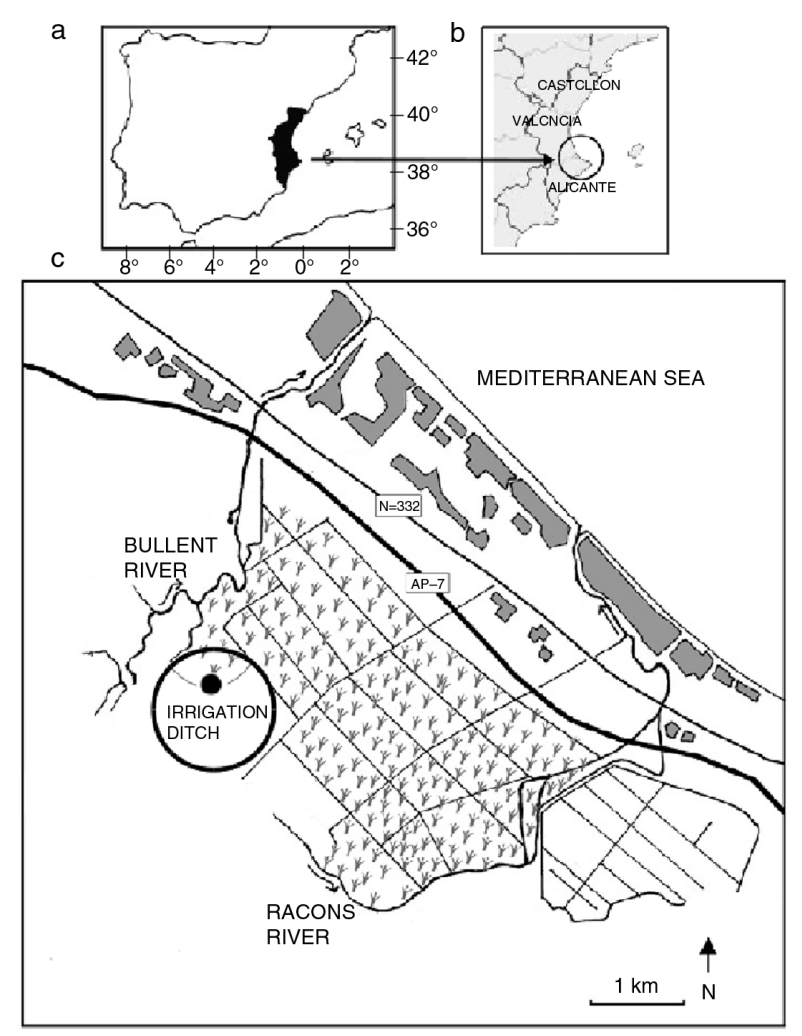

Fig. 1. Location of Pego-Oliva Natural Park (E Spain): a, in Valencia Autonomous Community; $b$, between the provinces of Valencia and Alicante; c, the sampling point is enclosed by a circle.
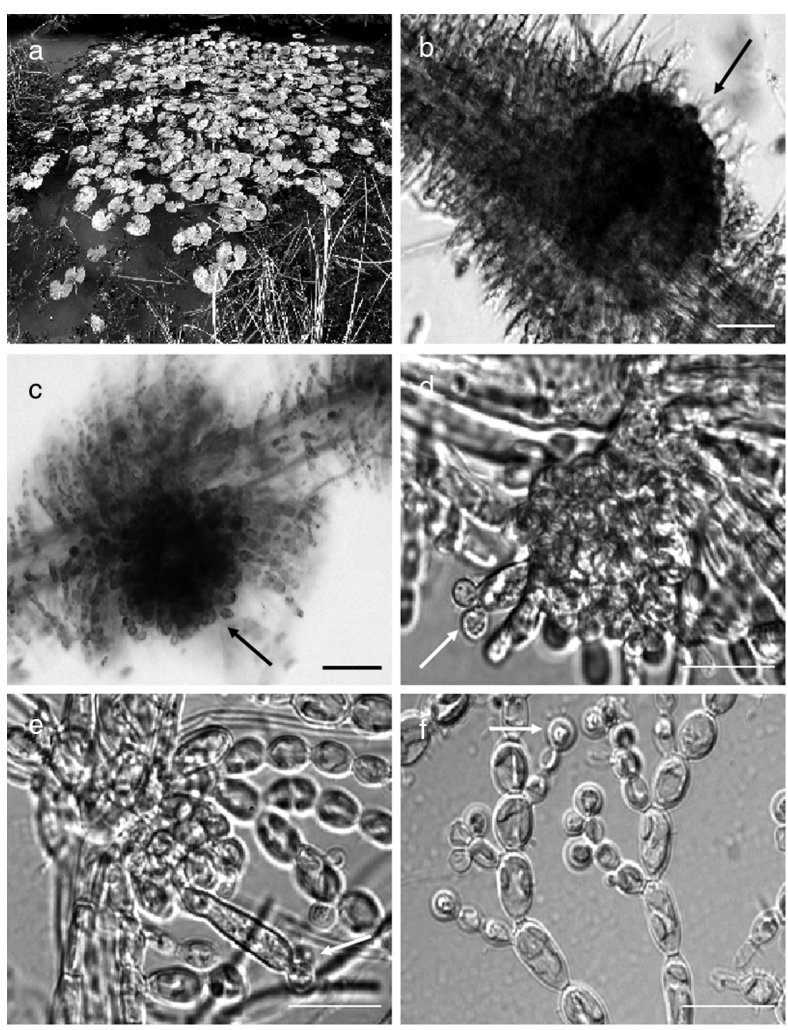

Fig. 2. a, Irrigation ditch in Pego-Oliva Natural Park where Kumanoa mahlacensis was collected, with Nymphaea alba as dominant species; b and $c$, main axis with pear-shaped whorls and single hemispherical carposporophyte inserted centrally (arrows); $d$ and e, carpogoniumbearing branches strongly undulated, arising from periaxial cells, trichogyne ellipsoidal or urn-shaped more or less stalked with attached spermatia (arrows); f, Spherical spermatangia terminal on fascicles [b-f, 5152 MUB-ALGAE]. Scale bar: $b-c=50 \mu m ; d-f=20 \mu \mathrm{m}$.

\section{Sampling and processing}

The specimens were collected during extensive seasonal sampling of different habitats of the wetland: rivers, sources, irrigation ditches, rice fields and salt water sources in the Natural Park. Water temperature, $\mathrm{pH}$, conductivity, dissolved oxygen, light intensity and current velocity were measured in situ with portable equipment. At the same time, water samples were collected, filtered (Millipore $0.45 \mu \mathrm{m}$ ) and frozen with liquid nitrogen in the field and kept at $-20{ }^{\circ} \mathrm{C}$ or refrigerated in the dark until further analysis in the laboratory. The water chemistry was analyzed $\left(\mathrm{NO}_{3}^{-} \mathrm{NO}_{2}^{-}\right.$, $\mathrm{PO}_{4}^{3-}$ and $\mathrm{Si}$ ) spectrophotometrically with MERCK kits (Spectroquant ${ }^{\top}$ ). The specimens were examined and measured with a stereomicroscope and a Leica DMRB microscope equipped with a computer program to scan images (Spot RT Software v3.0.). The morphological vouchers were included in the MUB Herbarium of the University of Murcia (5152 MUB-ALGAE).

\section{Molecular data analysis}

Fresh thalli were desiccated in silica gel and kept frozen at $-20{ }^{\circ} \mathrm{C}$. These samples were ground in liquid nitrogen, and DNA was extracted using the (NucleoSpin ${ }^{\text {TMM }}$ Plant (Clontech Laboratories Inc., Mountain View, CA, USA) following the 
manufacturer's protocol. Double-stranded PCR amplification was performed in an Applied Biosystems 2720 thermocycler (Applied Biosystems [ABI], Foster City, CA, USA) as previously described (Entwisle \& al., 2009). Polymerase chain reaction for $r b c \mathrm{~L}$ for a total volume of $100 \mu \mathrm{L}$ consisting of $2 \mu \mathrm{L}$ genomic DNA; $20 \mu \mathrm{M}$ each of dATP, dTTP, dGTP and $\mathrm{dCTP} ; 0.4 \mu \mathrm{M}$ of each primer; $2 \mathrm{mM} \mathrm{MgCl}_{2}$; and $10 \times$ reaction buffer with 1 unit of Taq Polymerase (Invitrogen, Carlsbad, CA, USA) (Entwisle \& al., 2009). A portion of the large subunit of ribulose 1,5-biphosphate carboxylase/oxygenase $(r b c \mathrm{~L})$ gene was amplified using primer pair F160 and $r b c \mathrm{LR}$ (Stewart \& Vis, 2007). The PCR product was purified using UltraClean $^{\mathrm{TM}}$ PCR Clean-up (Mo Bio Laboratories, Carlsbad, CA, USA) according to the manufacturer's protocol. The PCR product was sequenced using the ABI PRISM ${ }^{\mathrm{TM}}$ Big Dye Terminator v3.1 Cycle Sequencing Ready Reaction Kit (Applied Biosystems (ABI), Foster City, CA, USA) and an ABI 3100 Genetic Analyzer.

\section{Distribution and biogeography}

In order to study the distribution and biogeography of Kumanoa mablacensis, references from both the scientific literature and databases (Genbank) were compiled. This data set was overlapped in ArcMap (ESRI), with updated Köppen-Geiger climate classification maps provided by the Food and Agriculture Organization of the United Nations (1999).

\section{RESULTS AND DISCUSSION}

\section{Morphology}

Specimens from Pego-Oliva Natural Park consisted of monoecious thalli, $6 \mathrm{~cm}$ high, dark-greyish green, moderately mucilaginous. Whorls were pear-shaped, $220-340 \mu \mathrm{m}$ in diameter, abundantly and irregularly branched (Fig. 2b, c). Primary fascicles were dichotomously branched, 6-7 cellstoreys; secondary fascicles were numerous, 6-7 cell-storeys non- or dichotomously branched and covering the entire internode.

Carpogonium-bearing branches consisting of 5-15 barrelshaped cells, strongly undulated, arising from periaxial cells; carpogonia were 15-25 $\mu \mathrm{m}$ long, $4-5 \mu \mathrm{m}$ in diameter at the base and 7-8 $\mu \mathrm{m}$ in diameter at the apex; trichogyne were ellipsoidal or urn-shaped, more or less distinctly stalked (Fig. 2d, e). Carposporophytes were spherical or hemispherical, single or two per whorl, 125-155 $\mu \mathrm{m}$ in diameter, inserted centrally and lower than the whorl (Fig. 2b, c). Spermatangia were spherical $4-6 \mu \mathrm{m}$ in diameter, terminal on fascicles (Fig. 2f, Table 1).

Morphometric parameters of Spanish specimens were similar to those reported for specimens from Guam (Kumano \& Bowden-Kerby, 1986) and Thailand (Traichaiyaporn \& al., 2004) (Table 1). The specimens from Spain had slightly smaller whorl and carposporophyte diameters, and length of carpogonium than those from Guam and Thailand. All the diagnostic features and quantitative characteristics measured are within those given for the species in Necchi \& Vis (2012), except that this specimen extends the lower range of whorl diameter from $250 \mu \mathrm{m}$ to $220 \mu \mathrm{m}$.

\section{Environmental and ecological characteristics}

Specimens were collected in an irrigation ditch only in September with a water temperature of $20^{\circ} \mathrm{C}$, a pH of 7.5 and a conductivity of $610 \mu \mathrm{S} / \mathrm{cm}$ (Table 2 ). The same locality was visited in three other occasions during year 2009, but no gametophytes were observed. The annual average water temperature was $\sim 20^{\circ} \mathrm{C}$, the mean annual $\mathrm{pH}$ varied slightly $\sim 7$, dissolved oxygen remained around $8 \mathrm{mg} / \mathrm{L}$ and the incident radiation was relatively high. The nitrate concentration was high during the entire year with the maximum concentration in November and minimum in August. Nitrite, orthophosphate and silicate concentrations were low and remain fairly constant throughout the year.

The conductivity, nitrate and nitrite concentrations were higher in the Spanish wetland than in Thailand, but orthophosphate concentration was lower (Table 2). However, the temperature and the $\mathrm{pH}$ were very similar in all locations with measurements. In general, this species seems to have a wide ecological range: from irrigation ditches with high nutrient concentration to clean and shallow freshwater streams with slow flow (Kumano \& Bowden-Kerby, 1986; Traichaiyaporn \& al., 2004).

The aquatic vegetation of the irrigation ditch consisted of the macroalgae Cladophora glomerata (L.) Kützing, Coleochaete scutata Brébisson, Ulva flexuosa Wulfen, Batrachospermum cf. gelatinosum (L.) DC, Compsopogon coeruleus (Balbis ex C. Agardh) Montagne, Oedogonium sp., Spirogyra sp. and Mougeotia sp. and the angiosperms Nymphaea alba L., Ceratophyllum demersum L., and Myriopbyllum spicatum L., but $N$. alba was the dominant taxon occupying $80 \%$ of the water surface (Fig. 2a).

Table 1. Morphological comparison of Kumanoa mahlacensis from the irrigation ditch of Pego-Oliva Natural Park with the literature

\begin{tabular}{|c|c|c|c|c|c|c|c|c|c|c|c|}
\hline \multirow[b]{2}{*}{ Locality } & \multirow[b]{2}{*}{$\begin{array}{c}\varnothing \text { whorl } \\
\mu \mathrm{m}\end{array}$} & \multirow[b]{2}{*}{$\begin{array}{c}\mathrm{N}^{\circ} \mathrm{Cells} / \\
\text { primary } \\
\text { fascicles }\end{array}$} & \multirow[b]{2}{*}{$\begin{array}{l}\mathrm{N}^{\circ} \mathrm{Cells} / \\
\text { secondary } \\
\text { fascicles }\end{array}$} & \multicolumn{2}{|c|}{ Carposporophyte } & \multicolumn{4}{|c|}{ Carpogonium } & \multirow[b]{2}{*}{ Habitat } & \multirow[b]{2}{*}{ References } \\
\hline & & & & $\begin{array}{c}N^{\circ} / \\
\text { whorl }\end{array}$ & $\varnothing \mu \mathrm{m}$ & $\begin{array}{l}\mathrm{N}^{\circ} \text { Cells/ } \\
\text { carpogonial } \\
\text { branch }\end{array}$ & $\begin{array}{l}\text { Length } \\
\mu \mathrm{m}\end{array}$ & $\begin{array}{l}\varnothing \mu \mathrm{m} \text { at } \\
\text { the base }\end{array}$ & $\begin{array}{c}\varnothing \mu \mathrm{m} \text { at } \\
\text { the apex }\end{array}$ & & \\
\hline $\begin{array}{l}\text { Asia, } \\
\text { Thailand }\end{array}$ & $250-400$ & $7-9$ & $6-7$ & $1-2$ & $140-170$ & $5-15$ & $25-40$ & $4-5$ & $7-8$ & $\begin{array}{l}\text { Slow flowing } \\
\text { stream }\end{array}$ & $\begin{array}{l}\text { Traichaiyaporn } \\
\& \text { al. (2004) }\end{array}$ \\
\hline
\end{tabular}


Table 2. Comparison of physical and chemical variables for habitats of Kumanoa mahlacensis from Spain and the literature in collected dates

\begin{tabular}{|c|c|c|c|c|c|c|c|c|c|c|c|c|}
\hline Locality & $\begin{array}{l}\text { Time } \\
\text { year }\end{array}$ & $\begin{array}{c}\text { Temp } \\
{ }^{\circ} \mathrm{C}\end{array}$ & $\mathrm{pH}$ & $\begin{array}{c}\text { Conductivity } \\
(\mu \mathrm{S} / \mathrm{cm})\end{array}$ & $\begin{array}{c}\mathrm{O}_{2} \\
(\mathrm{mg} / \mathrm{L})\end{array}$ & $\begin{array}{c}\text { P.A.R. } \\
\text { Surface } \\
\left(\mu \mathrm{E} / \mathrm{cm}^{2} / \mathrm{s}\right)\end{array}$ & $\begin{array}{c}\text { P.A.R. } \\
\text { depth } \\
\left(\mu \mathrm{E} / \mathrm{cm}^{2} / \mathrm{s}\right)\end{array}$ & $\begin{array}{c}\mathrm{NO}_{3}^{-} \\
(\mathrm{mg} / \mathrm{L})\end{array}$ & $\begin{array}{c}\mathrm{NO}_{2}^{-} \\
(\mathrm{mg} / \mathrm{L})\end{array}$ & $\mathrm{Si}(\mathrm{mg} / \mathrm{L})$ & $\begin{array}{c}\mathrm{PO}_{4}^{-3} \\
(\mathrm{mg} / \mathrm{L})\end{array}$ & References \\
\hline Guam & July & 25 & 7.2 & - & - & - & - & - & - & - & - & $\begin{array}{l}\text { Kumano \& } \\
\text { Bowden- } \\
\text { Kerby (1986) }\end{array}$ \\
\hline Thailand & $\begin{array}{l}\text { Nov, } \\
\text { Jan }\end{array}$ & $19-21$ & 7.08-7.35 & $86.7-93.0$ & - & - & - & $0.5-1.7$ & $0.002-0.003$ & $6.57-7.60$ & $0.21-0.31$ & $\begin{array}{l}\text { Traichaiyaporn } \\
\& \text { al. (2004) }\end{array}$ \\
\hline
\end{tabular}

\section{Molecular data}

The sequence data of a $1282 \mathrm{bp}$ region of the $r b c \mathrm{~L}$ gene (Genbank number JQ713334) confirmed that the specimens collected in Pego-Oliva Natural Park belong to Kumanoa mablacensis. This specimen had $100 \%$ sequence identity with the two Genbank sequences (JN589006, JN589007) from New Mexico and Texas, respectively (Vis \& al., 2012). There are no sequence data for the type location in Guam or the report from Thailand (Kumano \& Bowden-Kerby, 1986; Traichaiyaporn \& al., 2004).

\section{Distribution and biogeography}

Kumanoa mablacensis has been reported from only five sites worldwide: Guam (Pacific Ocean), Thailand (Asia), New Mexico and Texas in the southwest US (North America), and in Pego-Oliva Natural Park, Spain (Europe) (Fig. 3).
According to Köppen-Geiger climatic zone, the species has been documented in 3 of 5 climatic regions, from Tropical regions (Kumano \& Boden-Kerby, 1986; Traichaiyaporn \& al., 2004) to Arid (Vis \& al., 2012) and Temperate regions, and in 4 of the 31 sub-climatic classes (Equatorial, Monsoon, Mediterranean and Desert), which were defined by temperature and precipitation conditions (Kottek \& al., 2006). The area where the specimens were collected in Spain is included in the Mediterranean thermoclimate with a subhumid ombroclimate (Rivas-Martínez, 1987).

Until recently, K. mablacensis was considered a tropical species (Kumano \& Boden-Kerby, 1986; Traichaiyaporn \& al., 2004), but it probably has a cosmopolitan distribution. A similar case occurred with Nostochopsis formerly considered a tropical genus, which also has a cosmopolitan distribution (Moreno \& al., 2012). Although Mediterranean wetlands are important refugees for biodiversity and are included in several International Conservation Treaties (Ramsar Convention

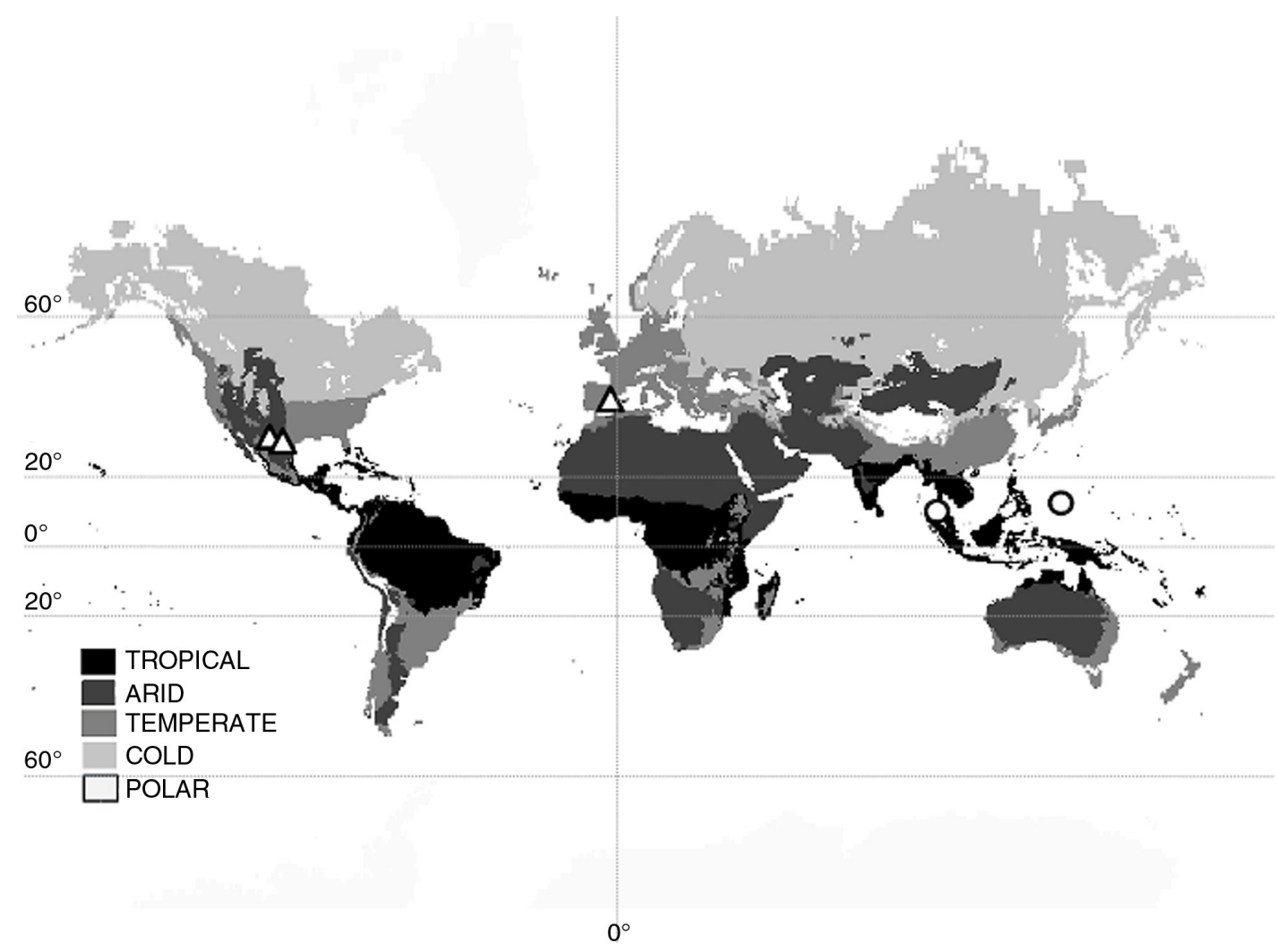

Fig. 3. World distribution of Kumanoa mahlacensis and climatic regions (Köppen-Geiger classification system). Triangles represent records with genetic data and circles are records without these data. 
Secratariat, 2011), the algal communities have been very poorly studied (Uhel \& al., 2010) and most likely other overlooked species will be discovered in future (Cantoral-Uriza \& Aboal, 2001; García- Fernández \& al., 2011). This work represents a new contribution to this effort.

\section{ACKNOWLEDGEMENTS}

This work was financially supported by the Autonomous Community of Murcia (PEPLAN-S5), Education and Science Ministry (CGL2006-09864), Science and Innovation Ministry (CGL2009-09563) and Ohio University Research Incentive. We thank Taylor Macy for her assistance in laboratory research.

\section{REFERENCES}

Boira, H. 1988. Flora y Vegetación del Marjal de Pego-Oliva. Ayuntamiento de Oliva. Valencia.

Bourrelly, P. 1970. Les algues d'eau douce. Les algues blenes et rouges. III. Ed. Boubée. París.

Cantoral-Uriza, E.A. \& Aboal, M. 2001. El Marjal Pego-Oliva: evolución temporal de las comunidades algales. Limnetica 20: 101-113.

Carretero, C.J.L. 1990. Macrófitos acuáticos de la provincia de Alicante. Medi Natural 2: 45-55.

Eloranta, P. \& Kwandrans, J. 2007. Freshwater red algae (Rhodophyta). Identification guide to European taxa, particularly to those in Finland. Norrlinia 15: 1-103. Saarijärvi.

Eloranta, P., Kwandrans, J. \& Kusel-Fetzmann, E. 2011. Rhodophyceae and Phaeophyceae. In: Schagerl, M. (eds.), Süßwasserflora von Mitteleuropa 7: 1-155. Spectrum Akademischer Verlag. Heidelberg.

Entwisle, T.J., Vis, M.L., Chiasson, W.B., Necchi, O. JR. \& Sherwood, A.R 2009. Systematics of the Batrachospermales (Rhodophyta) - a synthesis. Journal of Phycology 45(3): 704-715. http://dx.doi.org/10.1111/j.15298817.2009.00686.x

Food and Agriculture Organization of the United Nations (ed.) [2012] SD Dimensions Special, Digital maps and technical data. [http://www.fao. $\mathrm{org} / \mathrm{sd} /$ EIdirect/climate/EIsp0002.htm. Updated July 1999].

García-Fernández, M.E., Sánchez-Lorencio, M.I. \& Aboal, M. 2011. Algas aerofíticas del Marjal de Pego-Oliva, este de la Península Ibérica. Acta Botanica Malacitana 36: 169-174.

Israelson, G. 1942. The freshwater Florideae of Sweden. Studies on their taxonomy, ecology and distribution. Symbolae Botanicae Upsaliensis 6: $1-135$.

Kottek, M., Grieser, J., Beck, C., Rudolf, B. \& Rubel, F. 2006. World Map of the Köppen-Geiger climate classification updated. Meteorologische Zeitschrift 15: 259-263. http://dx.doi.org/10.1127/0941-2948/2006/0130

Kumano, S. 2002. Freshwater Red Algae of the World. Biopress Limited. Bristol.

Kumano, S. \& Bowden-Kerby, W.A. 1986. Studies on the freshwater Rhodophyta of Micronesia I. Six new species of Batrachospermum Roth. The Japanese Journal of Phycology 34(2): 107-128.

Moreno, J.L., Monteagudo, L. \& Aboal, M. 2012. On the presence of Nostochopsis lobata Wood ex Bornet et Flahault in Spain: morphological, ecological and biogeographical aspects. Nova Hedwigia 95: 373-390. http://dx.doi.org/10.1127/0029-5035/2012/0052

Necchi, O. JR. 1987. Studies on the freshwater Rhodophyta of Brazil 3 Batrachospermum brasiliense sp. nov. from the state of Sao Paulo, southern Brazil. Revista Brasileira de Biologia 47: 441-446.
Necchi, O. JR. \& Vis, M.L. 2012. Monograph of the genus Kumanoo (Batrachospermales, Rhodophyta). Bibliotheca Phycologia 116: 1-79.

Necchi, O. JR., Vis, M.L. \& Oliveira, M.C. 2010. Phylogenetic relationships in Kumanoa (Batrachospermales, Rhodophyta) species in Brazil with the proposal of Kumanoa amazonensis sp. nov. Phycologia 49(1): 97-103. http://dx.doi.org/10.2216/09-24.1

Ramsar Convention Secretariat, 2011. The Ramsar Convention Manual: a guide to the Convention on Wetlands. Gland. Switzerland.

Reis, M.P. 1965. Subsídios para o conhecimento das rodoficeas de agua doce de Portugal V. Boletim da Sociedade Broteriana 39(2): 137-157.

Reis, M.P. 1972. Batrachospermum henriquesianum, sp. nov. Boletim da Sociedade Broteriana 46(2): 181-190.

Reis, M.P. 1973. Subsídios para o conhecimento das rodoficeas de agua doce de Portugal VIII. Boletim da Sociedade Broteriana 47(2): 139-156.

Rivas-Martínez, S. 1987. Memoria del mapa de vegetación de España. ICONA. Madrid.

Sheath, R.G. \& Whittick, A. 1995. The unique gonimoblast propagules of Batrachospermum breutelii (Batrachospermales, Rhodophyta). Phycologia 34:33-38. http://dx.doi.org/10.2216/i0031-8884-34-1-33.1

Sirodot, S. 1884. Les Batrachospermes, organisation, functions, développément, classifications. Libraire de Académie de Médicine. París.

Stewart, S.A. \& Vis, M.L. 2007. Investigation of two species complexes in Batrachospermum Section Batrachospermum (Batrachospermales, Rhodophyta). Phycologia 46: 380-385. http://dx.doi.org/10.2216/ 06-86.1

Traichaiyaporn, S., Kumano, S., Chainapong, T., Khuantrairong, T. \& Waraegsiri, B. 2004. New Record of Freshwater Red Algae (Rhodophyta) in Thailand. Batrachospermum mablacense Kumano et Boden-Kerby. Science Asia 30(3): 313-315. http://dx.doi.org/10.2306/ scienceasia1513-1874.2004.30.313

Uhel, R., Spyropoulou, R., Breton, F., Beltrame, C., Arévalo, J., Richard, D., Martín-López, B., Lomas, P., Gómez-Baggethun, E., Tomas, P., Ezzine de Blas, D., Nichersu, I., Marin, E. 2010. Ecosystem accounting and the cost of biodiversity losses: the case of coastal Mediterranean wetlands. European Environment Agency. Copenhagen.

Viñals, M.J., Camarasa, A.M. \& Sendra, A. 1990. Factores de estabilidad en un humedal costero: la Marjal de Oliva-Pego. In: Gutiérrez, M., Peña J.L. \& Lozano M.V. (eds.), Actas $1^{a}$ Reunión Nacional de Geomorfogía I: 385-396. Instituto de Estudios Turolenses.

Vis, M.L., Chiasson, W.B. \& Sheath, R.G. 2005. Phylogenetic relationships of Batrachospermum species (Batrachospermales, Rhodophyta) from coastal streams in French Guiana. Phycologia 44: 441-446. http://dx.doi. org/10.2216/0031-8884(2005)1[441:PROBSB]2.0.CO;2

Vis, M.L. \& Entwisle, T.J. 2000. Insights into the phylogeny of the Batrachospermales (Rhodophyta) from $r b c \mathrm{~L}$ sequence data of Australian taxa. Journal of Phycology 36: 1175-1182. http://dx.doi. org/10.1046/j.1529-8817.2000.99224.x

Vis, M.L., Necchi, O. JR., Chiasson, WB. \& Entwisle, T.J. 2012. Molecular phylogeny of the genus Kumanoa (Batrachospermales, Rhodophyta) Journal of Phycology 48: 750-758. http://dx.doi.org/10.1111/j.1529. 8817.2012.01141.x

Vis, M.L., Saunders, G.W., Sheath, R.G., Dunse, K. \& Entwisle, T.J. 1998 Phylogeny of the Batrachospermales (Rhodophyta) inferred from $r b c \mathrm{~L}$ and 18S ribosomal DNA gene sequences. Journal of Phycology 34: 341-350. http://dx.doi.org/10.1046/j.1529-8817.1998.340341.x

Associate Editor: Javier Fuertes Received: 25-VII-2012 Accepted: 26-I-2014 